\title{
Retrospective analysis of Hepatitis B serology profiles of a cohort of Hepatitis B Surface antigen positive patients, Sri Lanka
}

\author{
Wirasinghe K ${ }^{1}$, Abeynayake J. I. ${ }^{2}$, Perera P. A. D. M. P. ${ }^{1}$, Galagoda G. ${ }^{2}$, \\ Nanayakkara S. S. J. ${ }^{2}$ Pradeepa S. K. ${ }^{2}$
}

\begin{abstract}
Introduction: Currently more than 350 million people are estimated to be chronically infected with Hepatitis B (HBV). The prevalence of HBV in Sri Lanka is estimated to vary between 0.1-2.5 percent. A detailed descriptive statistical analysis has not yet been performed on the available HBV serology profiles in Sri Lanka.

Objective: To describe the serology profiles of Hepatitis B surface antigen positive (HBsAg+) patients tested at the Medical Research Institute of Sri Lanka during 2007-2017

Methods: A sample of 517 test reports of patients with positive HBsAg was extracted during the period from 2007 to2017 for analysis. The serology profiling had been done using ELISA technique available at the time of testing. The data collected for each patient consisted of available data on the MRI request form which included age and gender.

Results: The mean age of the sample was 36 years ( $\mathrm{Mdn}=36,95 \% \mathrm{CI}=36-38$ years) and $5 \%$ of them were $<12$ years of age. Male to female ratio was 2:1. Out of 517 profiles, $23 \%$ (118) had serologically acute hepatitis, $12 \%$ (63) chronic hepatitis, $12 \%$ (63) early acute hepatitis, $3 \%(17)$ acute resolving hepatitis, $2 \%$ (10)immune tolerant or immune active chronic hepatitis, $11 \%(55)$ chronic HBeAg negative, and 3\%(18) chronic inactive carrier stage. Out of the total, $22.4 \%(116)$ were positive for $\mathrm{HBeAg}$ with high infectivity. HBeAg positivity among the age groups of $<10$ years, $11-19$ years, $>20$ years was $72 \%, 22 \%$ and $20 \%$ respectively. There was a significant difference in infectivity $(\mathrm{p}<0.05)$ among the three age groups.
\end{abstract}

Conclusions: More than 1/5 of HBV infected is of high infectivity. HBeAg positivity appears to be higher in the age group $<10$ years.

Key words: Hepatitis B serology profiles, Hepatitis B surface antigen positive.

Authors: ${ }^{1}$ Dr Wirasinghe K. (MBBS, PgDipVen; Registrar in Venereology), National STD AIDS control program, Sri Lanka. ${ }^{2}$ Dr Abeynayake J. L. (MBBS, Dip. Medical Micro, MD); Consultant Medical Virologist, Head, Department of Virology, Medical Research Institute(MRI), Sri Lanka. ${ }^{1}$ Dr Perera P. A. D. M. P., (MBBS, PgDipVen), MD; Senior Registrar in Venereology, National STD/AIDS Control Programme, Sri Lanka. ${ }^{2}$ Dr Galagoda G.,(MBBS, Dip. Medical Micro, MD); Consultant Medical Virologist, Department of Virology, MRI, Sri Lanka. ${ }^{2}$ Dr Nanayakkara S. S. J. , (MBBS, PgDip family medicine); Department of Virology, MRI, Sri Lanka. ${ }^{2}$ Pradeepa S. K., MLT, Department of Virology, MRI, Sri Lanka.

Copyright

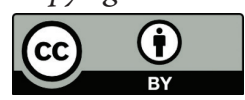

Corresponding author: ${ }^{1} D r . K$. Wirasinghe, Email; wirasinghekanchana@gmail.com Acknowledgement: Dr Ajith Karawita MBBS, PgDipVen, MD; Consultant Venereologist, Teaching Hospital, Anuradha-
pura.

Conflict of interest: No conflict of interest

Funding: No funding support for this study

Originality: This is an original work not published anywhere, presented at $23^{\text {rd }}$ Annual Scientific Sessions of Sri Lanka College of Sexual Health and HIV Medicine 2018

Submitted on:15.11.2018; Accepted on:30.12.2018 


\section{Full article}

\section{Introduction}

Currently more than 350 million people are estimated to be chronically infected with Hepatitis B (HBV).(1) Annual deaths due to HBV are around 780,000. (2) Exact prevalence of HBV infection in SL is unknown.It is estimated to vary between $0.1-2.5$ percent. (3)

HBV infection results in a spectrum of liver diseases ranging from acute hepatitis to chronic liver diseases.(3) With increasing age, the risk of chronicity decreases. The one to five age group has a $30 \%-50 \%$ risk whilst the adult group has a $6 \%-10 \%$ risk. There for prevention of infections in younger age groups is important.(4)

Staging, assessing severity and infectious status based on HBV profile can significantly improve disease prognosis. HBV profile inferred natural history and infectivity patterns among different age groups will help health care prevention measures against HBV. HBV markers helps in decision on management of $\mathrm{HBV}$ infection. Hepatitis $\mathrm{B}$ e Antigen $(\mathrm{HBeAg})$ testing is a qualitative marker of HBV replication, showing high infectivity and identifies individuals with a high risk of developing liver cancer.(5) Hepatitis B core Antibody (HB IgM and $\mathrm{HB} \operatorname{IgG}$ ) testing enables categorization into recent or chronic infection.

A detailed descriptive statistical analysis has not yet been performed on the available HBV serology profiles in Sri Lanka.

\section{Method}

Retrospective descriptive analysis of 517 test reports of patients with positive HBsAg was extracted from Medical Research Institute (MRI), during the period from 2007 to 2017. MRI is the reference laboratory for HBV testing in Sri Lanka. The data collected for each patient consisted of available data on the MRI request form which included age and gender. Data collection was done using a data extraction sheet. HBV profiles of same patient and incomplete HBV serology profiles were excluded.

The serology profiling was done using ELISA technique which was available at the time of testing. HBsAg positive samples were re-tested for hepatitis $B$ serology profile with ELISA. Serology profile contained; Hepatitis B core total ( $\mathrm{HBc}$ IgM and $\mathrm{HBc}$ IgG), Hepatitis B core IgM ( $\mathrm{HBc}$ IgM), Hepatitis B e Antigen (HBeAg), Hepatitis B e Antibody (HBeAb).
Data analysis was done using SPSS Statistics 17 and Microsoft Excel. Interpretation of hepatitis B serological markers was done using the United Kingdom National Guideline on the Management of the viral hepatitis A, B and C 2015.

\section{Results}

Out of the $517 \mathrm{HBsAg}$ positives, 293 (56\%) were males, 148 (29\%) were females and $76(15 \%)$ gender was not indicated.

The mean age of the sample was 36 years $(\mathrm{Mdn}=36$, $95 \% \mathrm{CI}=36-38$ years $)$ and $5 \%$ of them were $<12$ years of age.

\section{Table 1: Distribution by age}

\begin{tabular}{lr}
\hline Mean & 36 years \\
& $(95 \%$ CI=36-38 yrs. $)$ \\
\hline Median & 36 years \\
\hline Patients $<12$ years & $5 \%$
\end{tabular}

Out of 517 profiles, 23\% (118) had serologically acute hepatitis, 12\% (63) chronic hepatitis, 12\% (63) early acute hepatitis, 3\% (17) acute resolving hepatitis, $2 \%$ (10) immune tolerant or immune active chronic hepatitis, $11 \%$ (55) chronic $\mathrm{HBeAg}$ negative, and 3\% (18) chronic inactive carrier stage.

\section{Table 2: Distribution by disease state}

\begin{tabular}{lcr} 
Disease State & No & $\%$ \\
Early acute hepatitis & 63 & $12 \%$ \\
\hline Acute resolving hepatitis & 17 & $3 \%$ \\
\hline $\begin{array}{l}\text { Immune tolerant or immune } \\
\text { Active chronic hepatitis }\end{array}$ & 10 & $2 \%$ \\
\hline Chronic HBeAg negative & 55 & $11 \%$ \\
\hline Chronic inactive carrier stage & 18 & $3 \%$ \\
\hline
\end{tabular}

Out of the total, $22.4 \% \quad(n=116)$ were positive for $\mathrm{HBeAg}+$ with high infectivity. Majority $78 \%$ $(n=116)$ were negative for $\mathrm{HBeAg}$.

There was a significant difference in $\mathrm{HBeAg}$ positivity ( $\mathrm{p}=0.000196$ ) between $<10$ year age group and 11-19 year age group. There was a significant difference in $\mathrm{HBeAg}$ positivity ( $\mathrm{p}=0.00001$ ) between $<10$ year age group and 11-19 year age group.

The prevalence of $\mathrm{HBe} \mathrm{Ag}$ positivity was similar for the two sexes $(p=0.466)$ 
Table 3: HBeAg positivity distribution by age category

\begin{tabular}{lrrr} 
Age Category & $\begin{array}{r}\text { HBeAg } \\
\text { Negative } \\
<10 \text { years }\end{array}$ & $\begin{array}{r}\text { HBeAg } \\
\text { positive }\end{array}$ & Total \\
\hline $11-19$ years & $28 \%$ & $72 \%$ & $4 \%$ \\
\hline$>20$ years & $78 \%$ & $22 \%$ & $10 \%$ \\
\hline Total & $80 \%$ & $20 \%$ & $86 \%$ \\
\hline
\end{tabular}

Table 4: HBeAg positivity distribution by gender

\begin{tabular}{lrrr} 
& \multicolumn{1}{l}{$\begin{array}{l}\text { HBeAg } \\
\text { positive }\end{array}$} & \multicolumn{1}{c}{$\begin{array}{l}\text { HBeAg } \\
\text { negative }\end{array}$} & Total \\
Females & $25 \%$ & $75 \%$ & $26 \%$ \\
\hline Males & $24 \%$ & $76 \%$ & $74 \%$ \\
\hline Total & $22 \%$ & $78 \%$ & $100 \%$ \\
\hline
\end{tabular}

Twenty four were $\mathrm{HBc}$ total negative, $\mathrm{HBc} \operatorname{IgM}$ positive, $\mathrm{HBeAg}$ negative and $\mathrm{HBeAb}$ positive. Therefore $19.8 \%$ of acute hepatitis patients had developed antibodies, thus has become less infective.

\section{Discussion}

Male:Female ratio was 2:1 and mean age of the sample was 36 years. The age distribution and Male:Female ratio of the sample was comparable to data from the epidemiology unit, SL.(2) Somewhat similar trends were reported in a study done in Gujarat, India.(6) However since this study was a lab record based one, it could not comment on Sri Lankan population level data.

In areas where the disease is rare, $\mathrm{HBV}$ transmission is found to be most frequent through intravenous drug use and sexual transmission.(3) The age, gender and mean age(36 yrs, 95\% CI=36-38 yrs) of HBsAg positive individuals correlates with such methods of transmission. But proper clinical studies are needed to prove this.

Following HBV infection, development of hepatitis B core IgM antibodies are followed by development of $\mathrm{HBc}$ IgG antibodies. Categorization in to acute and chronic infection is possible with the presence of $\mathrm{HBc}$ IgM class antibodies, which persists only during the first 6 months of infection.(5) In this study, out of 517 profiles, $23 \%(n=118)$ had serologically acute hepatitis (IgM positives) and $12 \%(n=63)$ chronic hepatitis (IgM negative but IgG positive). HBsAg positive patients were not followed up for 6 months to categorize to chronic hepatitis B stage, which was a study limitation. Liver enzymes and HBV DNA viral load was not available to differentiate Chronic immune tolerant HBV infection from Immune active chronic hepatitis.

$\mathrm{HBeAg}$ positivity was $22 \%$, this highly infectious fraction contributes to maintain the viral transmission. It predicts the future burden of liver cancer.(5) Similar trends have been observed in a study done in Taiwan.(7)

A proportion of $\mathrm{HBV}$ infected persons are $\mathrm{HBeAg}$ negative due to mutations in the precore or core promoter regions of the HBV genome which prevents HBeAg formation.(8) Detection of these mutations was not done in this study. Therefore, the actual $\mathrm{HBeAg}$ positive proportion could be higher.

$\mathrm{HBeAg}$ positivity among $<10$ year age group was $72 \%$. Significant difference in infectivity $(\mathrm{p}<0.05)$ was observed compared to other three age groups. Higher $\mathrm{HBeAg}$ positivity among younger ages have been observed in studies done in Taiwan and Nigeria.(7,9) HBeAg seroconversion has been shown to be infrequent amongst children. (8) HBeAg seroconversion tends to occur in the second decade of life in $70 \%$ to $80 \%$ of childhood acquired infections. Also it had been shown that HBeAg negative infection(pre core mutant) occurs infrequently in children.(8) High $\mathrm{HBeAg}$ positivity rates amongst less than 10 year age group could be explained by these facts. But future clinical studies are needed to prove such findings.

It was not known whether less than 10 year group category had acquired the HBV infection perinataly since in-depth analysis of this age group was not done.

Infant $\mathrm{HBV}$ vaccination was introduced to the EPI in Sri Lanka in 2003.(3) A study in 2014, in Kaluthara district showed $76 \%$ protective levels of HBsAb status amongst children (1-5 years), despite $100 \% \mathrm{HBV}$ vaccination status.(2)

Infectivity patterns also need to be monitored through HBeAg testing. During childhood, horizontal transmission through infected saliva and blood is the most common method of transmission. (3) Therefore, strengthening the vaccination and infection control measures for all contacts of hepatitis B infected children needs to be considered. 


\section{Conclusions}

This study shows the importance of strengthening the hepatitis B surveillance, vaccination and infection control measures for all contacts of hepatitis B infected.

More than 1/5 of HBV infected is of high infectivity. HBeAg positivity appears to be higher in the age group $<10$ years.

\section{References}

1. Hou J, Liu Z, Gu F .Epidemiology and prevention of hepatitis B virus infection. Int Med Sci. 2005;2(1):50-57

2. Palihawadana P. World Hepatitis Day 2015: Hepatitis prevention [Internet]. Slideshare.net. 2015[cited28September2018].Availablefrom:https:// www.slideshare.net/Venereologists/world-hepatitis-day2015-hepatitis-prevention

3. A review of Hepatitis B virus infection in Sri Lanka .Noordeen,FNN Pitchai,RA Rafeek. Sri Lankan Journal of Infectious Diseases 2015 Vol.5 (2):42-50

4. Palihawadana P. Update on Hepatitis B and C. 2017;44(45):4.

5. Galagoda G. World Hepatitis Day 2015: Hepatitis B diagnosis and vaccination [Internet]. Slideshare.net. 2015 [cited 28 September 2018]. Available from: https:// www.slideshare.net/Venereologists/world-hepatitis-day2015-hepatitis-prevention

6. Patel DA, Gupta PA, Kinariwala DM, Shah HS, Trivedi GR, Vegad MM. An investigation of an outbreak of viral hepatitis B in Modasa town, Gujarat, India. J Glob Infect Dis. 2012 Jan 1;4(1):55-9.

7. Yang HI, Lu SN, Liaw YF, You SL, Sun CA, Wang LY, Hsiao CK, Chen PJ, Chen DS, Chen CJ.Hepatitis B e antigen and the risk of hepatocellular carcinoma. New England Journal of Medicine. 2002 Jul 18;347(3):168-74.

8. Brook G, Bhagani S, Kulasegaram R, Torkington A, Mutimer D, Hodges E, Hesketh L, Farnworth S, Sullivan V, Gore C, Devitt E. United Kingdom National Guideline on the Management of the viral hepatitides A, B and C 2015. International journal of STD \& AIDS. 2016 Jun;27(7):501-25.

9. Forbi JC, Iperepolu OH, Zungwe T, Agwale SM. Prevalence of hepatitis B e antigen in chronic HBV carriers in north-central Nigeria. Journal of health, population, and nutrition. $2012 \mathrm{Dec} ; 30(4): 377$. 